\title{
Urethral Squamous Cell Carcinoma
}

National Cancer Institute

\section{Source}

National Cancer Institute. Urethral Squamous Cell Carcinoma. NCI Thesaurus. Code C6165.

A well differentiated, moderately differentiated, or poorly differentiated squamous cell carcinoma that arises from the male or female urethra. 